Article

\title{
Techno-Economic Assessment of Three Modes of Large-Scale Crop Residue Utilization Projects in China
}

\author{
Liang Meng ${ }^{1,2,3}$, Ahmed Alengebawy ${ }^{1} \mathbb{D}$, Ping Ai ${ }^{1,2,3}$, Keda Jin ${ }^{1}$, Mengdi Chen ${ }^{1}$ \\ and Yulong Pan ${ }^{4, *}$ \\ 1 College of Engineering, Huazhong Agricultural University, Wuhan 430070, China; \\ mengliang2006@mail.hzau.edu.cn (L.M.); ahmed.alengebawy@yahoo.com (A.A.); \\ aiping@mail.hzau.edu.cn (P.A.); jinkeda@webmail.hzau.edu.cn (K.J.); antler@webmail.hzau.edu.cn (M.C.) \\ 2 Key Laboratory of Development and Application of Rural Renewable Energy, Ministry of Agriculture, \\ Chengdu 610041, China \\ 3 Cooperative Innovation Center for Sustainable Pig Production, Wuhan 430070, China \\ 4 Wuhan Electronic Information Institute, Wuhan 430019, China \\ * Correspondence: hpgroups@163.com
}

Received: 5 July 2020; Accepted: 17 July 2020; Published: 20 July 2020

\begin{abstract}
In China, the non-exploitation of bioenergy poses major problems and challenges. To solve bioenergy problems, considerable efforts have been made to expedite the construction of large-scale crop residue utilization projects. In this study, three principal supported modes of large-scale crop residue utilization projects were taken as empirical cases in Hubei province bioenergy planning. In terms of the overall benefit and sustainable development, a third-grade evaluation index system was established. The analysis was carried out using the analytical hierarchy process, principal component projection, and grey relational analysis. The conclusion indicates that according to the evaluation values, the sequence from best to worst was crop residue biogas project, crop residue briquette fuel project, and crop residue gasification project. Nevertheless, there was no remarkable difference in the overall evaluation values. The biogas project had certain advantages in terms of the production cost, soil improvement, and expenditure saving, whereas the gasification project was comparatively insufficient in environmental efficiency, product benefit, by-product disposal, and technical rationality. According to actual evaluation results, the unilateral determination approach of the single weight index can be seen as being overcome through the unified adaptation of the evaluation methods. The research results can serve as a reference for making investment decisions to build large-scale crop residue utilization projects.
\end{abstract}

Keywords: bioenergy projects; crop residue utilization; biogas; AHP; evaluation; decision making

\section{Introduction}

Despite the rapid development of Chinese energy production, there are energy shortage problems (especially bioenergy problems) that need innovative solutions. China is one of the largest agricultural countries. In 2009, the amount of agricultural residue in China was $716 \mathrm{Mt}$ (million tons), most of which was from rice straw [1]. In addition, Wang et al. [2] stated that in 2008-2009, China's annual production of crop residues was $750.3 \mathrm{Mt}$, including about $88 \%$ field residues and $12 \%$ process residues. Maize, rice, and wheat contribute the greatest percentage of the total quantity of crop residues. In 2010, China's total output of crop residue was estimated to be more than $700 \mathrm{Mt}$ annually [3], which is equivalent to 350 Mtce (million tons of coal equivalent). Furthermore, according to the National Bureau of Statistics of China (NBSC, Beijing, China), it was reported that the crop residue production in China 
during the period 2007-2016 increased from 725.47 Mt to 897.06 Mt [4]. A predictive study done by Ji [5] used an artificial neural network (ANN) model to estimate the annual production of crop residue, where the results showed that about $930 \mathrm{Mt}$ was produced annually. The results were almost consistent with the reports of the NBSC.

Chinese rural and developed areas have limited use of bioenergy, which consumes crop residue (CR) and agricultural wastes in biogas production projects [6]. Additionally, the amount of energy used for living and agricultural production is not enough. Moreover, the industrialized utilization of $\mathrm{CR}$ in rural areas is also restricted by some problems, such as discrete distribution and difficulty of transportation [7]. Such difficulties cause an extremely severe excess of CR. In addition, crop straw burning in the open farmlands is considered a challenging problem since it is hard to inhibit and causes severe environmental pollution [8,9]. Additionally, crop straw burning is the primary source of significant hazardous effects on human health and climate change [10]. To overcome the problems of renewable energy, the goal of China's strategy on bioenergy was to emphasize the rational utilization of CR, especially through large-scale utilization projects [11-13]. The CR biogas project is one of the essential methods used for the recycling of agricultural waste. In recent years, the central Chinese government has especially invested in the construction of CR biogas projects [14,15]. Subsequently, the annual production target of biomass briquette fuel of about $50 \mathrm{Mt}$ was set up in the mediumand long-term development plan. Thus, the large-scale utilization projects of CR, such as biogas, gasification, and briquette fuel projects, began to have rapid growth and were gradually incorporated as having central importance in bioenergy development [16-18]. As an empirical case, CR biogas, gasification, and briquette projects (including solidification and carbonization) were proposed in the bioenergy medium- and long-term development plan in Hubei province. These proposed projects referred to a new technology that should be significantly accelerated to enhance the utilized quantity of CR $[19,20]$. Recently, there have been many studies on the comprehensive evaluation index of bioenergy projects [21,22], However, as part of the comprehensive evaluation of the economic benefits using this multi-index description, most methods use a direct holistic comparison after removing the dimensionality and introducing normalization, that is, they transform the actual values of the different indexes describing the multiple dimensions of the evaluated objects into dimensionless evaluation values and synthesize these evaluation values into one-dimensional evaluation values to make a holistic evaluation of the evaluation objects. These studies only adopted a single evaluation method for the evaluation indicators but did not compare the various methods to find out the advantages and disadvantages of the various methods. The lack of uniform and standardized evaluation criteria makes it difficult for the evaluation results to be convincing; however, since the projects mentioned above pertain to burgeoning projects, there is no referential experience. Consequently, there is a lack of scientific analysis and decision-making tools, which is an obstacle to selecting suitable construction projects. To choose the construction project model more reasonably and scientifically, three modes of CR utilization projects constructed on a large scale were creatively proposed in this study. The benefits and costs of each project were contrasted, analyzed, and comprehensively evaluated. The evaluation results can provide a reference for the investment decision of large-scale CR utilization projects.

\section{Three Modes of Large-Scale Crop Residue Utilization Project}

With the rapid development of science and technology, there are multiple methods and processes used for CR utilization in the bioenergy field. In terms of scale, the process can be classified into household-scale or large-scale utilization [9]. A household CR gasifier and household CR biogas are both found in a wide range of household-scale utilizations. Referring to the large-scale utilization projects, the biogas, gasification, and briquette fuel projects (including solidification and carbonization) of $C R$ have recently been considerably enhanced to extend the utilization modes of bio-resources. The three modes of CR utilization are briefly introduced as follows. 


\subsection{The CR Gasification Project}

Gasification is a promising technology for bioenergy conversion that aims to convert biomass into syngas [23-25]. The CR gasification project aims to obtain combustible gas with a high heating value by taking crop straw as the raw material of the gasification process [26]. The gasifier used in CR gasification technologies can be classified into three types: fluidized bed, fixed bed, and entrained flow gasifiers [27,28]; among the three types, the fixed bed gasifier is widely used [29]. In the gasification reaction, air is most frequently used as the reaction medium. Furthermore, steam and hydrogen can also be used as a reaction medium, which is called the gasification agent [30]. The gasification device is composed of several key components, such as the combustion chamber, gasification chamber, inlet, and exhaust pipes. In the gasification chamber (with a high temperature and hypoxia), the thermochemical reaction of $\mathrm{CR}$ is carried out to generate combustible gases, which are mixed with hydrogen, carbon monoxide, methane, etc. [11]. The gasification technology can be classified into centralized and decentralized gasification. A CR gasification project that uses centralized gasification technology is mainly applicable to the straw-centralized regions. The project can supply household combustible gas for bioenergy consumption and is mainly suitable for rural areas where residents live centrally [31,32].

Biomass gasification is an effective approach to produce syngas, which used as biofuel and a power generator. The thermochemical process includes gasification as the most common way to convert biomass into biofuel and power via syngas cleaning. Usually, four main steps are used to produce syngas: drying, pyrolysis, reduction, and combustion [33]. Syngas can be utilized to generate power via a combined heat and power (CHP) generation system. In addition, syngas can be used in the internal combustion engine (ICE) for power generation [34]. Syngas is widely used in natural gas networks, boilers, electrical applications, and lighting.

Nowadays, the gasification technology is the most practical one among the biomass thermochemistry conversion technologies. In addition, there are three by-products obtained from the gasification process. The first is solid charcoal, which has the highest utilization value and the highest yield. Moreover, it has high amounts of fixed carbon, a low volatile content, and a more developed void structure, and thus the reaction activity is very high; this not only makes it an excellent solid fuel but it is also widely used in the chemical industry, food industry, environmental protection, and agriculture. The other two are liquid tar and pyrrolidine acid (wood vinegar). The tar produced by biomass gasification has the characteristics of complex composition, variable nature, comprehensive influential factors, and can cause great harm. The existence of tar seriously affects the gasification efficiency, leads to the waste of energy, and easily leads to the blockage of pipes [35,36]. Moreover, in the process of gasification, the production of tar should be minimized. For pyrrolidone acid, its main component is acetic acid, it has a low $\mathrm{pH}$, and a pungent odor. Refined wood vinegar can be directly used as a soil fungicide, can effectively control coniferous seedling stand blight, or can be used as a deodorant and in food spices. Crude methanol and wood vinegar can be obtained by further distillation of wood vinegar. Although the by-products can be utilized by the regasification process to reduce the level of pollution, the technique of application and market are still not formed [37,38]. The gasification system processes are shown in Figure 1. 


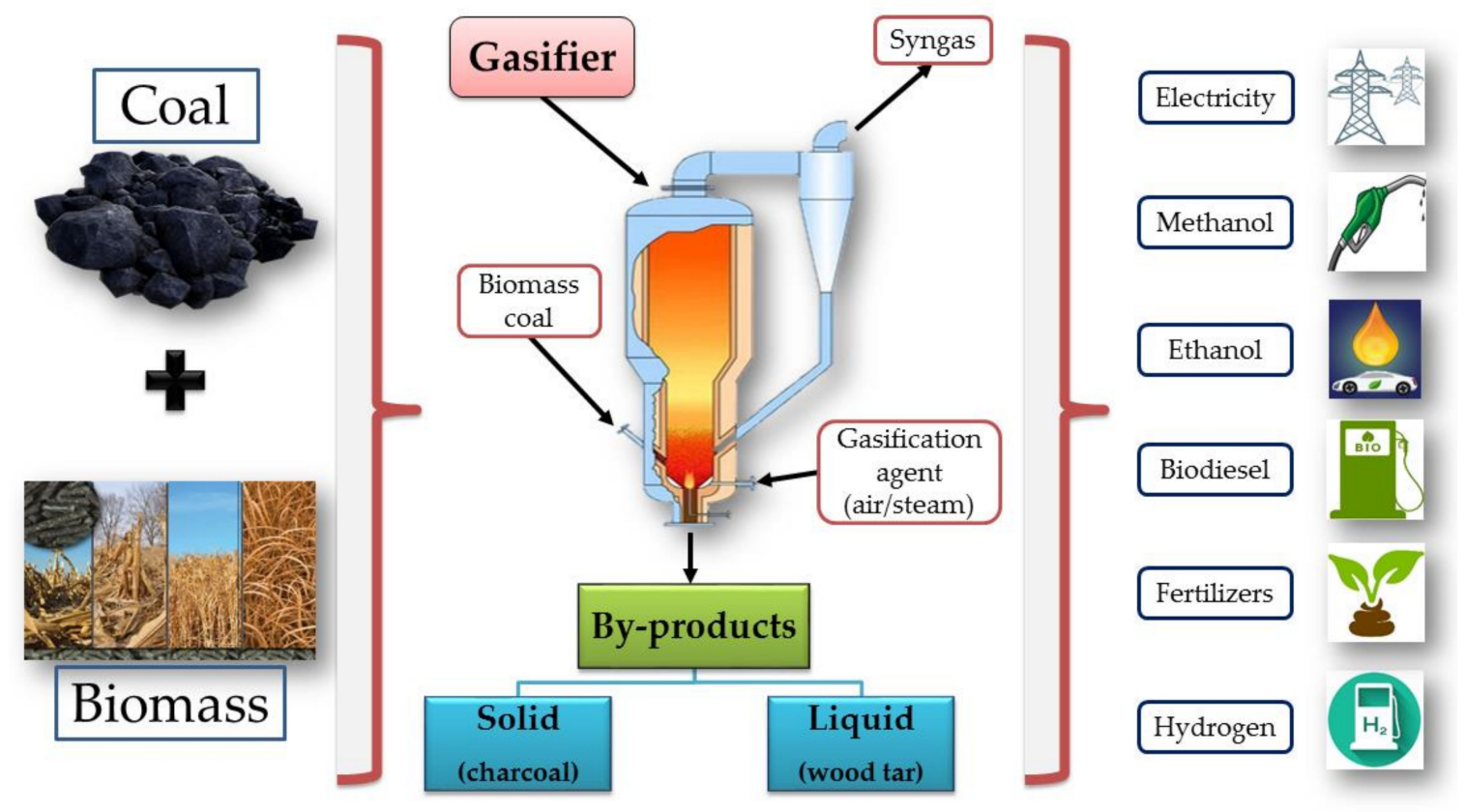

Figure 1. Schematic diagram of gasification processes.

\subsection{The CR Biogas Project}

A CR biogas project is a favorable approach to waste disposal that is used as an alternative to crop residue burning, which reduces environmental pollution, as well as producing clean bioenergy [39-41]. Usually, a CR biogas project adopts the anaerobic digestion technology. Anaerobic digestion (AD) is a sequence of biological processes for the digestate, where one of its end products is biogas [42]. The benefits from $\mathrm{AD}$ processes can be categorized into energy production, livestock manure recycling, and the production of biofertilizers [43,44]. Although anaerobic digestion achieves satisfactory rates in the production of biogas and methane, there are numerous problems that mono-anaerobic digestion cannot solve, such as carbon to nitrogen $(\mathrm{C} / \mathrm{N})$ ratio limitation, process inhibition, low buffering capacity, drop in $\mathrm{pH}$, and slow fermentation process [45,46]. Here, anaerobic co-digestion (AcoD) plays an effective role in overcoming the deficiencies of the mono-AD of agricultural waste. AcoD is a promising technology for high-value biogas production that involves the digestion of a mix of several substrates. AcoD can enhance the process's performance, improve the buffering capacity and moisture content, balance the $\mathrm{C} / \mathrm{N}$ ratio, and regulate the $\mathrm{pH}$, which results in the enhancement of biogas and methane production. As a case study, AcoD can enhance biogas production from $25 \%$ to $400 \%$ compared with the mono-AD [47]. Therefore, AcoD is considered an optimization of the mono-AD method $[48,49]$.

Different assessments can be considered to emphasize the feasibility of CR biogas projects, such as choosing the proper biogas system [50], the substances used for biogas production [51,52], the size of the biogas plant [43], and the obtained digestate [53]. A large-scale biogas plant operates on the feedstock of crop waste [54]. Typically, the biogas is distributed by pipelines to households from the central biogas tank. Besides biogas production, biogas residue can be used as organic fertilizer [55]. Compared with taking manure as the feedstock, the advantages of taking CR as the feedstock are that it is easy and convenient to obtain, store, transport, etc. [56]. It breaks through the limitation of livestock-manure-based biogas projects, which can only be established in large and medium poultry and animal plants. Because the CR biogas has a high total solid concentration, it is easier to dehydrate and utilize. Moreover, the biogas residue of a project with a feedstock of CR is much better than that of a project with the feedstock of livestock manure [57]. Biogas is widely used as a major source of biofuel production and power generation. Biofuel, including solid, liquid, and gaseous fuels, can be produced from raw biogas. Biofuel production mainly depends on methane $\left(\mathrm{CH}_{4}\right)$ concentration and 
purification. Several processes for obtaining high-value biofuel from raw biogas include separation, scrubbing, and purification [58]. Furthermore, through cogeneration, biogas can be used in power generation in the CHP generation system. Biogas applications are common, such as in biofuel cells, heat and power generation, electricity generation, boilers, and engines [59].

Besides biogas production, two by-products can be obtained: biogas residue (solid) and biogas slurry (liquid). These by-products contain rich organic matter and more humic acid; they are not only high-quality base fertilizers but also good soil modifiers. The application of biogas residue and biogas slurry can increase the soil aggregate structure, increase the porosity in the soil, and coordinate the water, fertilizer, gas, and heat conditions in the soil [55]. A large amount of data shows that the use of biogas liquid and biogas residue can promote the growth and yield of crops [42], improve the ability of crops to resist drought and insect pests, and improve the quality of crops to some extent, but there is no conclusive research on the effect of the long-term application on the soil. The biogas slurry of the $\mathrm{CR}$ projects can also be recycled to be applied as a humidity control with the primary raw material; thus, the volume of sewage discharged into the environment decreases [60]. Therefore, the utilization of biogas residue has great potential for development. Figure 2 presents a schematic diagram of an integrated biogas system.

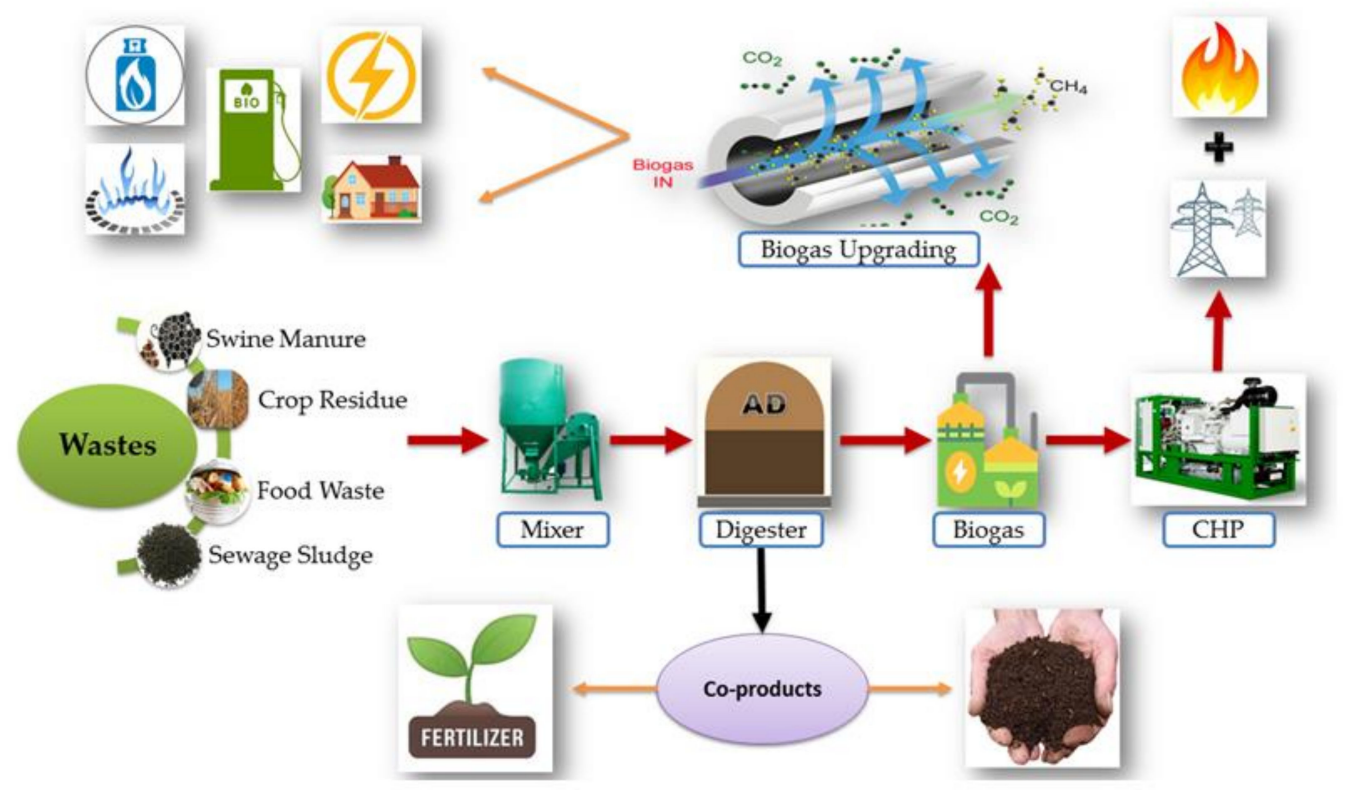

Figure 2. Schematic diagram of biogas production processes. CHP: Combined heat and power.

\subsection{The CR Briquette Fuel Project}

The briquetting process is the conversion of agricultural waste, such as rice straw, into molds that have a specific shape, which facilitates the handling of such materials in some processes, such as transportation and storage. A CR briquette project molds various lignocellulose materials, such as straw, rice husk, wood, sawdust, and firewood, into briquette fuel. Rice straw is frequently used as a raw material in bioenergy production [61]. However, due to the existence of lignin, the biodigestibility becomes low, which means the bioassimilation of cellulose and hemicellulose becomes limited [62]. In addition, the large bulk volume of rice straw increases the operation cost. Furthermore, rice is a seasonal crop that is not available all year [63]. For all the previous reasons, it is the role of the briquetting process to provide feasibility to CR utilization for bioenergy production $[64,65]$. Briquetting is based on a series of processes in which waste materials are used to form the molding block. To make the molding block, first, the $\mathrm{CR}$ must be ground to specific particle size. At the same time, humidity control and adding adhesives should also be emphasized [66,67]. 
The molding block is formed by an extrusion machine. The density of the block is significantly enhanced, which is more favorable for storage and transportation. The molding block can be applied directly for burning, as well as used to generate gas, pyrolytic oil, or machine-made wood charcoal by combining it with a CR pyrolytic process [68]. However, the main barrier of the briquette process utilization lies in the extrusion machine. Because the extrusion parts are easily worn out, the extrusion machine often cannot run for long periods [20]. Biomass briquette as an alternative fuel is an environmentally friendly and renewable energy; moreover, it is a green energy that is widely promoted all over the world. Briquette fuel can reach zero emissions during combustion, that is, no slag, no smoke, no sulfur dioxide, and other harmful gases. Furthermore, the carbon dioxide emission is close to zero, and after combustion, the carbon powder can be used as high-quality potassium fertilizer that can be put back on the field to improve soil fertility. Therefore, it is considered an efficient solution to reduce environmental pollution.

The use of briquettes as a source of biofuel production is widely preferred due to the high demand for green energy. To consider the briquettes as a fuel, the produced briquettes should have a high enough mechanical strength and calorific value. It is also common to mix charcoal with other substrates to enhance bioenergy production [69]. Fuel briquettes can be used in households for cooking, space heating, steam generation, and water heating. Figure 3 summarizes the process of briquette fuel production from agricultural wastes.

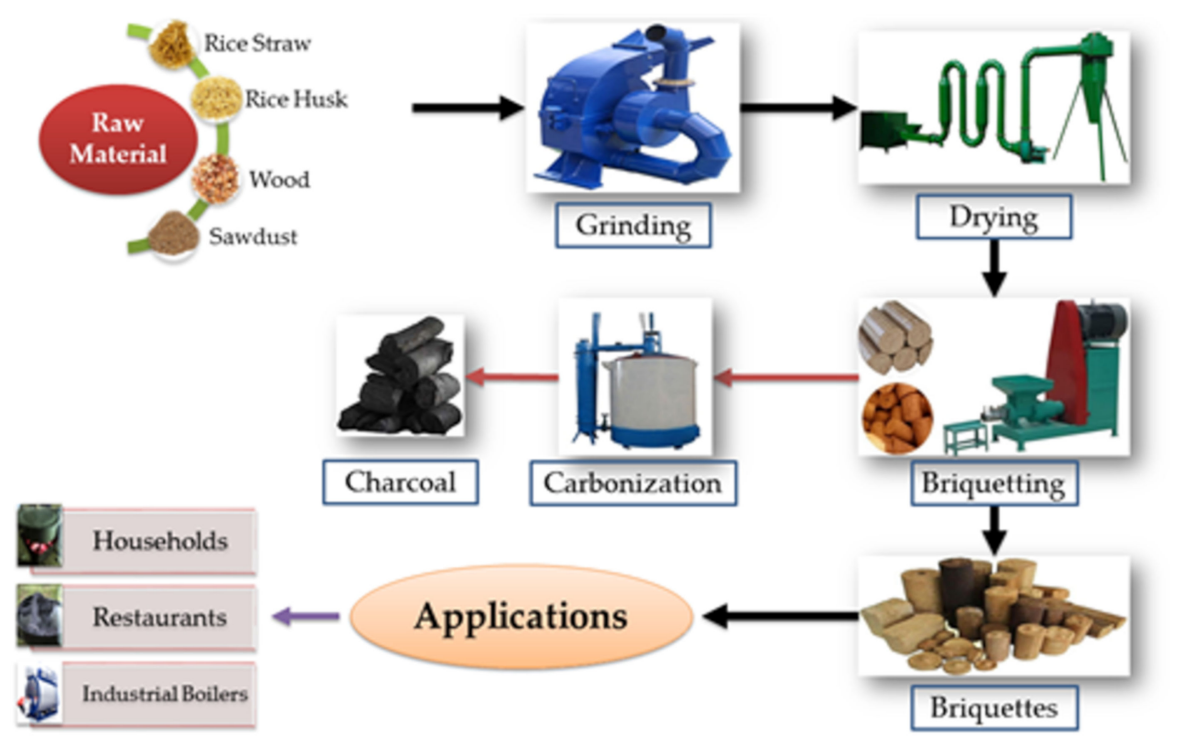

Figure 3. Schematic diagram of briquette fuel processes.

The three modes of large-scale CR utilization projects mentioned above were all proposed in the "13th Five-Year Plan (2016-2020)" for bioenergy in Hubei province, China. The government of Hubei Province would provide subsidies to support the construction of these projects. If the project was approved after government evaluation, it would receive certain subsidies according to different modes. The following are the subsidy standards for the three modes of CR utilization projects: for the biogas project, the average cost is about 4 million CNY, and its subsidy is 1.6 million CNY; for the gasification project, the average construction cost is about 5 million $\mathrm{CNY}$, and its subsidy is 2.1 million CNY; and for the briquette project, the cost and subsidy are 2 million and 1 million CNY, respectively. As shown in Table 1, principal information is given on the condition that projects are constructed according to the subsidy standards, and this study gives a comprehensive evaluation of three projects. 
Table 1. Fundamental data of the three types of large-scale crop residue (CR) utilization projects.

\begin{tabular}{ccccccc}
\hline Project Modes & $\begin{array}{c}\text { Fixed Cost } \\
\text { (Million CNY) }\end{array}$ & $\begin{array}{c}\text { Variable Cost } \\
\text { (Million CNY) }\end{array}$ & $\begin{array}{c}\text { Number of Supplied } \\
\text { Households }\end{array}$ & $\begin{array}{c}\text { CR Consumption } \\
\text { (Tons/Year) }\end{array}$ & Yield Per Year & $\begin{array}{c}\text { Number of } \\
\text { Employees }\end{array}$ \\
\hline Biogas & 4 & 0.203 & 300 & 1000 & $2.7 \times 10^{5} \mathrm{~m}^{3}$ & 3 \\
Gasification & 5 & 0.443 & 1000 & 2000 & $4 \times 10^{6} \mathrm{~m}^{3}$ & 10 \\
Briquette & 2 & 0.575 & - & 2500 & $2380 \mathrm{t}$ & 12 \\
\hline
\end{tabular}

\section{Establishment of the Evaluation Index System and Index Scoring}

\subsection{Evaluation Indexes}

To conduct a comprehensive plan for the three projects, an assessment of the three modes of projects needs to be carried out. Recently, many researchers have proposed various assessment indexes and evaluation models in the field of biomass energy [70-74]. In this study, to acquire comprehensive benefits and promote sustainable development, a third-grade index system of evaluation was established, as shown in Figure 4.

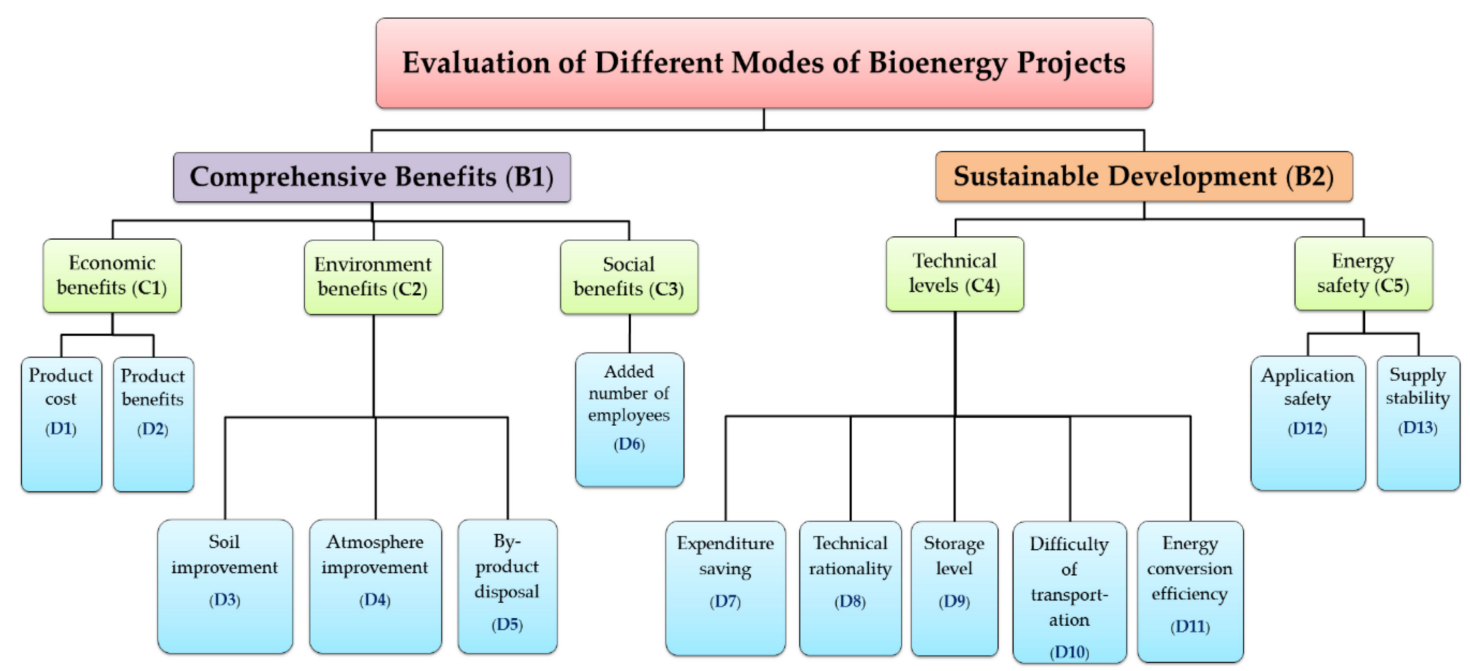

Figure 4. Evaluation index system for the project of crop residue utilization.

\subsection{Explanation of the Indexes and Scoring}

The evaluation index system is comprised of 13 indexes, which can be categorized into two groups: quantitative indexes and qualitative indexes. For the quantitative indexes, they can be assessed using specific quantitative data with different dimensions that should be performed using dimensionless procedures. For the qualitative indexes, they cannot be evaluated as a directly measured value; therefore, the quantitative method of a pairwise judgment matrix is frequently applied to obtain an exact value. By combining the quantitative and qualitative indexes, a comprehensive evaluation index system could be established.

\subsubsection{Quantitative Indexes and Quantization}

- $\quad$ Product cost (fixed and variable cost)

The fixed cost indicates the one-time fixed asset investment made for its construction, while the variable cost indicates the varying cost according to the scale of operation, including expenses for the raw material, energy consumption, wages, maintenance, etc., where the price of the CR raw material is calculated to be 120 Chinese Yuan (CNY)/ton. Moreover, combining the CR annual consumption (Table 1) can provide the cost of the raw material used in each project [75-77], while the variable costs can be found in Table 2. 
Table 2. Variable costs of the three project modes (unit: million CNY per year).

\begin{tabular}{cccc}
\hline Costs & Biogas & Gasification & Briquette \\
\hline Raw material & 0.12 & 0.24 & 0.30 \\
Electricity & 0.05 & 0.10 & 0.15 \\
Equipment maintenance & 0.40 & 0.70 & 1.00 \\
Salaries & 0.03 & 0.10 & 0.12 \\
Total & 0.60 & 1.14 & 1.57 \\
\hline
\end{tabular}

- Product benefits (direct product and by-product benefits)

The CR biogas, CR gasification, and CR briquette fuel projects can make combustible gas of $4 \times 10^{6} \mathrm{~m}^{3}$ and $2.7 \times 10^{5} \mathrm{~m}^{3}$, and molding fuel of $2380 \mathrm{t}$ per year, respectively. The market price of the $\mathrm{CR}$ biogas, gasified gas, and briquette fuel is $1.5 \mathrm{CNY} / \mathrm{m}^{3}, 0.3 \mathrm{CNY} / \mathrm{m}^{3}$, and $450 \mathrm{CNY} / \mathrm{t}$, respectively. The direct product benefit is $0.405,1.200$, and 1.071 million CNY, respectively. Among the by-product benefits, the CR biogas can generate $2500 \mathrm{t}$ of biogas slurry and $500 \mathrm{t}$ of residue fertilizers per year, in which the slurry is seldom processed and utilized. The CR manure was calculated to have a value of $100 \mathrm{CNY} / \mathrm{t}$; thus, the annual profit of the by-product is 0.05 million CNY [60]. While the CR gasification project has a by-product of $400 \mathrm{t}$ of wood carbon and $70 \mathrm{t}$ tar per year, where the price of wood carbon is $1800 \mathrm{CNY} / \mathrm{t}$ and tar is $2500 \mathrm{CNY} / \mathrm{t}$ currently; thus the annual profit from the gasified by-product is 0.895 million CNY [78]. In total, the overall annual profit from CR biogas, gasification, and briquette fuel is $0.455,2.095$, and 1.071 million CNY, respectively.

- Soil improvement

The biogas slurry and biogas residue generated by a CR biogas project can enhance the soil organic matter, humic acid content, and soil looseness if it is put back on the field. The long-term application can increase the fertilizer use ratio and flesh up the soil. In addition, applying the biogas residue as a crop fertilizer to the soil can enhance soil fertility, plant growth, and crop yield $[42,79,80]$. Due to the reduced application amount of fertilizer and improving the crop yield and the agricultural product quality, the profit for a hectare is about 450 CNY. In addition, a CR biogas project may provide fertilizer for about 66 ha of soil; therefore, its profit from soil improvement is approximately 0.03 million CNY.

- Atmosphere improvement

Based on the substitution ratio of fossil energy, it can be concluded that CR biogas, CR gasification, and $C R$ briquette fuel projects can save 300, 180, and $7200 \mathrm{t}$ of coal, respectively. From the reduction equation, it can be calculated that a $\mathrm{CR}$ biogas project can reduce $129.66 \mathrm{t}$ of $\mathrm{CO}_{2}$ and $4.02 \mathrm{t}$ of $\mathrm{SO}_{2}$; each CR gasification station can reduce about $315 \mathrm{t}$ of $\mathrm{CO}_{2}$ and about $3.6 \mathrm{t}$ of $\mathrm{SO}_{2}$; and a $\mathrm{CR}$ briquette fuel project can reduce about $3700 \mathrm{t}$ of $\mathrm{CO}_{2}$ and $12 \mathrm{t}$ of $\mathrm{SO}_{2}$ every year [81].

- By-product disposal cost

Each CR gasification project can produce about $300 \mathrm{t}$ of wood acid per year $[37,82]$. The wood acid disposal cost is about $25 \mathrm{CNY} / \mathrm{t}$; thus, the overall annual wood acid disposal cost is $7500 \mathrm{CNY}$. Due to absorption failure, $60 \%$ of the $2500 \mathrm{t}$ biogas slurry generated per year by a CR biogas project needs to be disposed of at a current cost of $4.4 \mathrm{CNY} / \mathrm{t}$; thus, the total disposal cost of biogas slurry is $6600 \mathrm{CNY}$.

- Number of employed persons

According to the standard subsidies mentioned above, the labor force required for each large-scale project is responsible for taking charge of the daily raw material treatment, equipment operation, and maintenance, etc. In the CR biogas, gasification, and briquette projects, the required numbers of employed persons are 3,10 , and 12 , respectively. 
- $\quad$ Expenditure saving

The CR biogas and gasification projects reduce household living expenses through centrally supplying combustible gas. Compared with traditional energy, a CR biogas project can save $350 \mathrm{CNY}$ in fuel fees and 350 CNY in organic fertilizer expenses for a household per year; a CR gasification project can save $300 \mathrm{CNY}$ in energy fees for a household every year; and CR briquette fuel is not promoted in household life directly, and thus, the expenditure saving is $0 \mathrm{CNY}$.

The evaluation value of the above quantitative indexes (D1-D7), seen in Figure 5, was obtained after the dimensionless and normalized treatment.

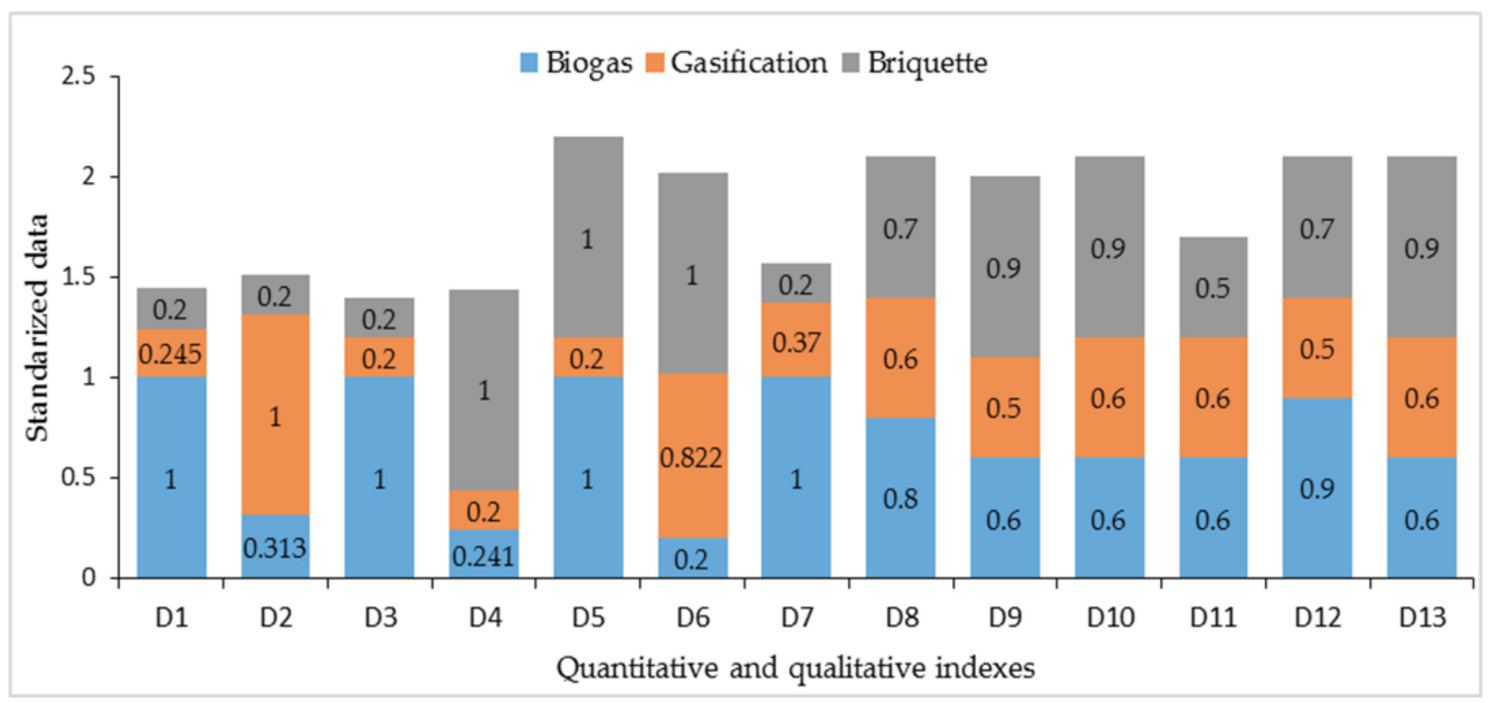

Figure 5. Dimensionless and normalized evaluation matrix.

\subsubsection{Qualitative Indexes and Analysis}

- Technical rationality

The analysis should be made from various aspects, such as technical constraints, equipment fault ratio, and the automation degree of the production line. By taking technical constraints as an example, the main technical problems of a CR biogas project are the CR pretreatment and fungicide cost problem. However, the main problems confronted by the CR gasification project are tar gathering and purification disposal techniques. Furthermore, the main problems of the CR briquette fuel technology are the low output, high energy consumption, fast wearing-out of crucial components, and inadequate continuous working ability.

- Storage level

Storage of any material, whatever its physical state (solid or liquid), requires specific conditions. Regarding CR biogas and CR gasification projects, the energy storage level depends on the volume of the gas tank. The storage performance of the CR briquette fuel is relatively better than the other two projects.

- Transportation convenience

As for the range of the centralized gas supply, considerations should be given to CR gathering, storage, transportation radius, transfer pressure, etc.; generally, the radius is within $5 \mathrm{~km}$. Among the three project modes, the transportation of CR briquette fuel is more convenient.

- Energy conversion efficiency 
The energy conversion is mainly analyzed from the aspects of gasification efficiency, briquette ratio, heat value, thermal burning efficiency, etc.

- Application safety

One of the components of the $\mathrm{CR}$ gasification gas is carbon monoxide (CO), which may bring the potential risk of poisoning during applications. An explosion potential also exists because of the possibility of oxygen entering the system, which may increase in the case of starting and stopping gas production during the operating interval in the gasification station. The application safety is relatively high for CR biogas and CR briquette fuel projects.

\section{- $\quad$ Supply stability}

The gas supply stability of CR biogas is influenced by the natural temperature and incoming and outgoing materials. In addition, the gas supply stability at the time of the gas-consuming peak of the CR gasification project is influenced by the unit discharge capacity, whereas the CR harvest seasonally influences the CR briquette fuel supply stability.

The evaluation values of the qualitative indexes (D8-D13), seen in Figure 5, were obtained using pairwise judgment matrix.

\subsubsection{Standardized Evaluation Matrix}

First, by adopting the following two equations and a smoothing value of 0.2 , the index value was processed to be dimensionless and normalized to facilitate the evaluation [83]:

$$
\begin{aligned}
y_{i} & =\frac{x_{i}-x_{\min }}{x_{\max }-x_{\min }}, \\
y_{i} & =\frac{x_{\max }-x_{i}}{x_{\max }-x_{\min }},
\end{aligned}
$$

where $y_{i}$ refers to the $i$ th normalized value and $x_{i}$ is the original value. However, if the evaluation index $i$ is positive, Equation (1) should be adopted; conversely, if it is negative, then Equation (2) should be applied. Therefore, the standardized data in Figure 5 was derived using the evaluation matrix $Y=\left(y_{i j}\right)_{3 \times 13}$.

\section{Evaluation Models and Results Analysis}

Three evaluation models were involved in this study to conduct a comprehensive evaluation of the three bioenergy project modes. The first evaluation model used the analytic hierarchy process (AHP), the second model used a principal component projection (PCP), and the third one used grey relational analysis (GRA). The three models have different ways to determine the weight index. For the AHP, the weight index is established mainly based on the subjective judgment of experts according to their experiences [84]. For the PCP, the weight index is calculated using the pertinent matrixes. The value of the objective relevance was dependant on each index [85]. As for the GRA, the ideal index was determined first, and then the weight index was assessed according to the correlation between the index sequence and the optimal data sequence [75]. Therefore, the three evaluation models can complement each other in the application and avoid one-sidedness or the limitation of using a single evaluation model.

\subsection{Principles of the AHP}

The critical procedure of the rational AHP evaluation is the weight index determination $[76,86]$. The following are the weight index calculating steps:

(1) Determine the importance weight index value of the evaluation index relative to the upper layer index by adopting a pairwise comparison method and build the judgment matrix $A=\left[a_{i j}\right]_{\mathrm{n} \times \mathrm{n}}$ [87] 
by adopting a 1-9 ratio scale, in which $a_{i j}>0, a_{i j}=1 / a_{j i}, a_{i i}=1$, where $a_{i j}$ refers to the scale value, which compares between index $i$ and index $j$.

(2) From $A W=\lambda_{\max } W$, the characteristic vector of $W$ can be obtained and then normalized to calculate the weight index vector $W=\left[w_{1}, w_{2}, \ldots, w_{n}\right][88]$.

(3) For the consistency check, calculate the consistency index (CI) [83,89] by applying Equation (3):

$$
C I=\frac{\lambda_{\max }-n}{n-1}, \lambda_{\max }=\frac{1}{n} \sum_{i}\left(\frac{\left(A W_{i}\right)}{w_{i}}\right),
$$

Thus, the consistency ratio (CR) can be calculated using $C R=C I / R I_{(n)}$, where $\lambda_{\max }$ is the maximum eigenvalue, while $R I$ refers to the random index, which can be obtained via the look-up table; if $C R<0.1$, then it can be acceptable.

(4) Construct the judgment matrix based on the expert's evaluations using the calculation mentioned above (Table 3) such that the final weight index $W_{1}$ can be obtained using Equation (4), as presented in Hazelrigg [90]:

$$
B_{i}=\sum_{j=1}^{n} w_{j} \times y_{j}(j),
$$

where $B_{i}$ indicates the overall evaluation value of mode $i$, which is presented in Table 4 .

Table 3. Weight index evaluation of the analytic hierarchy process (AHP) and the principal component

\begin{tabular}{|c|c|c|c|c|c|c|c|c|c|c|c|c|c|c|c|c|c|}
\hline & & & & & D1 & D2 & D3 & D4 & D5 & D6 & D7 & D8 & D9 & D10 & D11 & D12 & D13 \\
\hline \multirow{5}{*}{ G } & \multirow{3}{*}{ B1 } & \multirow{3}{*}{0.600} & C 1 & 0.500 & 0.400 & 0.600 & 0 & 0 & 0 & 0 & 0 & 0 & 0 & 0 & 0 & 0 & 0 \\
\hline & & & C 2 & 0.300 & 0 & 0 & 0.250 & 0.250 & 0.500 & 0 & 0 & 0 & 0 & 0 & 0 & 0 & 0 \\
\hline & & & C 3 & 0.200 & 0 & 0 & 0 & 0 & 0 & 0.250 & 0.750 & 0 & 0 & 0 & 0 & 0 & 0 \\
\hline & \multirow{2}{*}{ B2 } & \multirow{2}{*}{0.400} & C 4 & 0.625 & 0 & 0 & 0 & 0 & 0 & 0 & 0 & 0.330 & 0.170 & 0.170 & 0.330 & 0 & 0 \\
\hline & & & C 5 & 0.375 & 0 & 0 & 0 & 0 & 0 & 0 & 0 & 0 & 0 & 0 & 0 & 0.500 & 0.500 \\
\hline \multirow{2}{*}{\multicolumn{5}{|c|}{$\begin{array}{l}\text { Difference vector of } \operatorname{AHP}\left(W_{1}\right) \\
\text { Difference vector of } \operatorname{PCP}\left(W_{2}\right)\end{array}$}} & 0.120 & 0.180 & 0.045 & 0.045 & 0.090 & 0.030 & 0.090 & 0.083 & 0.043 & 0.043 & 0.083 & 0.075 & 0.075 \\
\hline & & & & & 0.130 & 0.241 & 0.040 & 0.120 & 0.140 & 0.058 & 0.220 & 0.003 & 0.015 & 0.009 & 0.002 & 0.013 & 0.009 \\
\hline
\end{tabular}
projection (PCP).

Table 4. Evaluation results and sequencing order.

\begin{tabular}{ccccc}
\hline Project Modes & AHP $/ \mathbf{B i}$ & $\mathbf{P C P} / \mathbf{P i}$ & GRA/Ri & Overall Rank \\
\hline Biogas & $0.698(1 \mathrm{st})$ & $0.160(2 \mathrm{nd})$ & $0.651(1 \mathrm{st})$ & 1st \\
Gasification & $0.533(3 \mathrm{rd})$ & $0.099(3 \mathrm{rd})$ & $0.448(3 \mathrm{rd})$ & 3rd \\
Briquette & $0.549(2 \mathrm{nd})$ & $0.353(1 \mathrm{st})$ & $0.608(2 \mathrm{nd})$ & 2nd \\
\hline
\end{tabular}

\subsection{Principles of the $P C P$}

The PCP utilizes a matrix transformation. Among the indexes in the evaluation matrix, to find an answer to the problem of overlapping information, the original index is transformed into mutually orthorhombic indexes. In addition, dimensionless and weighting processing should be applied to the evaluation matrix first. Then, ideal decision-making vectors should be designed. Later, take each evaluation object project to the ideal vectors as the one-dimensional evaluation index in terms of the projection value of the decision-making vector [77]. The calculation steps are as follows:

(1) Determine the weight index: Usually, the weight index is determined by adopting the entropy method [91]. This method is applied to the evaluation matrix to obtain the weight index vector $W_{2}=\left[w_{1}, w_{2}, \ldots, w_{n}\right]$, which can be found using Table 3 . Then, process the weight index of the evaluation matrix by setting $z_{i j}=w_{i j} y_{i j}$ such that the matrix $Z=\left(z_{i j}\right)_{\mathrm{m} \times \mathrm{n}}$ is obtained and the evaluation vector $d_{i}=\left(z_{i 1}, z_{i 2}, \ldots, z_{i n}\right), i=(1,2, \ldots, m)$ is produced.

(2) Index orthogonal transformation [92]: Set the characteristic value of matrix $Z_{i}=\left(\lambda_{1}, \lambda_{2}, \ldots\right.$, $\left.\lambda_{m}\right)$, where $\lambda_{1} \geq \lambda_{2}, \ldots, \geq \lambda_{m} \geq 0$ and its corresponding characteristic vector is $\sigma=\left(\alpha_{1}, \alpha_{2}, \ldots\right.$, $\left.\alpha_{\mathrm{m}}\right)$. Form the matrix $A=\left(\alpha_{1}, \alpha_{2}, \ldots, \alpha_{\mathrm{m}}\right)$ and then apply an orthogonal transformation to the 
matrix $Z$ by setting $U=Z A=\left(u_{i j}\right)_{m \times n}$ such that the new evaluation vector is $d_{i}=\left(u_{i 1}, u_{i 2}, \ldots\right.$, $\left.u_{\text {in }}\right), i=(1,2, \ldots, m)$ will be obtained.

(3) Calculate the projection value [92]: First, build the ideal sample as $d^{*}=\left(d_{1}, d_{2}, \ldots, d_{\mathrm{n}}\right)$, in which $d_{j}=\max _{1 \geq j \geq n}\left\{u_{i j}\right\}$ where $i=(1,2, \ldots, m)$. Then, calculate the unit vector $d_{0}^{*}$ in the direction of $d^{*}$ using Equation (5):

$$
d_{0}^{*}=\frac{1}{\left\|d^{*}\right\|} d^{*}=\frac{1}{\sqrt{d_{1}^{2}+d_{2}^{2}+\cdots+d_{n}^{2}}} d^{*}
$$

Finally, calculate the projection value $P_{i}$ using Equation (6):

$$
P_{i}=d_{i} \times d_{0}^{*}=\frac{1}{\sqrt{d_{1}^{2}+d_{2}^{2}+\cdots+d_{n}^{2}}} \sum_{j=1}^{n} d_{j} u_{i j}
$$

where $i=(1,2, \ldots, m)$. Then, create a sequence according to the projection value $P_{i}$ of the different evaluation objects, where the larger the projection value, the better the results. The evaluation matrix $Y$ was utilized to obtain the weight index $W_{2}$ using MatLab version 7.10.0. The MathWorks Inc., (Natick, MA, USA); the demonstration project scoring $P_{i}$ and the ranking order was also obtained and is shown in Table 3.

\subsection{Principles of the GRA}

The evaluation of the GRA is based on the relevancy between the evaluated scheme and the comparatively ideal scheme. The optimal data column $Y_{0}(k)$ was selected from the value of the evaluation matrix indexes $Y$ [93]. The steps for calculating the relevancy are as follows:

(1) Calculate the relevancy coefficient $\varepsilon_{(0 \mathrm{i})}(\kappa)$ [94] using Equation (7):

$$
\varepsilon_{\left(0_{i}\right)}(k)=\frac{\min _{i} \min _{k}\left|Y_{0}(k)-Y_{i}(k)\right|+\rho \max _{i} \max _{k}\left|Y_{0}(k)-Y_{i}(k)\right|}{\left|Y_{0}(k)-Y_{i}(k)\right|+\rho \max _{i} \max _{k}\left|Y_{0}(k)-Y_{i}(k)\right|},
$$

where $Y_{0}(k)$ refers to the series of experimental results, $Y_{i}(k)$ is the series of influenced factors, $i=(1,2, \ldots, m)$, and $k=(1,2, \ldots, n) . \rho$ is the distinguishing coefficient [95] which was taken as 0.5 [96]. Then, the relevancy coefficient matrix can be obtained using Equation (8):

$$
\varepsilon=\left\{\varepsilon_{\left(0_{i}\right)}(k)\right\}_{m \times n^{\prime}}
$$

(2) Calculate the relevancy using Equation (9), as presented in Aslan et al. [97]:

$$
R_{i}=\frac{1}{n} \sum_{k=1}^{n} \varepsilon_{\left(0_{i}\right)}(k),
$$

The value of relational grade $R_{i}$ is shown in Table 4, which indicates the relevancy between $Y_{i}$ and the ideal column $Y_{0}$.

\subsection{Comprehensive Evaluation Results and Analysis}

Comparing the weight index vectors $W_{1}$ and $W_{2}$ of the AHP and the PCP, the indexes that had a higher weight index were the product cost, product benefit, by-product disposal, expenditure saving, and the technical rationality. The evaluation results of the three models are listed in Table 4. The sequencing results of the three models were consistent, except for some sequencing differences of the biogas and briquette projects by the PCP-based model. Based on the evaluation result, the ranking order of the three project modes was biogas, briquette, and gasification from best to worst; the sequencing 
result indicates that the biogas project was superior according to the overall benefit and sustainable development. The gasification project was comparatively inferior when compared to the other two project modes.

According to the value of the evaluation vector, we found that the biogas project of CR had several advantages, for example, the product cost, expenditure saving, and soil improvement. At the same time, it was inferior in several aspects, such as the product benefit and transportation convenience. The briquette project of CR had an excellent storage level performance, good supply stability, and convenience in transportation, while it was deficient in product cost, expenditure saving, and energy conversion efficiency.

A CR gasification project is relatively inferior in terms of technical rationality, by-product disposal, environment efficiency, and product benefit. Overall, there was no remarkable difference in the total evaluation of each project. Therefore, considerations shall be given to the requirements of the owners, farmers, and government, in addition to the actual local situation, to select the appropriate project mode in combination with the advantages and disadvantages of three modes.

\section{Technical Challenges in Practical Applications and Future Research Perspectives}

Recently, domestic research on creating comprehensive evaluation indexes for bioenergy projects is mostly focused on the economic benefit index of biomass energy utilization projects. Moreover, there is less consideration of sustainable development indicators and there is no comparative study of various project models; therefore, it is difficult to find a constructed model that is most suitable for local rural areas. According to their characteristics, this study established a third-grade comprehensive evaluation index system to compare, analyze, and evaluate CR gasification, CR biogas, and CR briquetting fuel projects. This evaluation system applied three evaluation methods together: AHP, PCP, and GRA. Although it overcame the one-sidedness of a single weight-determination method, at the same time, the accuracy requirements for each index data became higher. Therefore, in future practical application processes, more accurate acquisition of raw data is needed to reduce the calculation error, which makes the processing requirements for data higher and requires a greater workforce for repeated sampling. However, the evaluation method provides the basis for the construction mode selection of key projects in the future to some extent and provides a reference value for the analysis and evaluation method research of other green energy project models.

\section{Conclusions}

The crop residue utilization was planned to be expedited in the bioenergy field during the period of the "13th Five-Year Plan (2016-2020)" for Hubei province, China. Consequently, the three modes of the large-scale CR utilization projects were listed as the demonstration projects in Hubei province, which might be provided with financial subsidies by the provincial government following specific standards. To evaluate the three projects, a third-grade evaluation index system was established. All the necessary data for each project were compared and analyzed by comprehensively adopting AHP, PCP, and GRA methods. According to the analysis results, the conclusions could be drawn out as follows:

(1) Based on the inclusive objective of overall benefit and sustainable development, up to 13 indexes were chosen to constitute the bottom layer of the evaluation index system, which consisted of quantitative (D1-D7) and qualitative (D8-D13) indexes. The final matrix of the evaluation was obtained using quantization, comparative scoring, removing dimensions, and normalization. Based on the matrix, through a unified utilization of the three AHP, PCP, and GRA models, the unilateral disadvantages of the determination methods of the single weight index were controlled. According to the results obtained for the biogas, gasification, and briquette projects, the overall evaluation values $(\mathrm{AHP} / \mathrm{Bi}$ ) were $0.698,0.533$, and 0.549 , respectively; the projection values $(\mathrm{PCP} / \mathrm{P} i)$ were $0.160,0.099$, and 0.353 , respectively; and the relational grades were 0.651 , 
0.448 , and 0.608 , respectively. Therefore, the final ranking order of the three modes was CR biogas, CR briquette, and CR gasification from best to worst.

(2) The CR biogas project had advantages in terms of the product cost, soil improvement, and expenditure saving. The CR gasification project was comparatively insufficient in environmental efficiency, product benefit, by-product disposal, and technical rationality. Nevertheless, there was no remarkable difference between the three modes in the total evaluation values. In other words, in theory, the comprehensive benefits of the three project models were almost similar in the evaluation system composed of 13 underlying indicators. In addition, the advantages and disadvantages of the three modes were also analyzed using the evaluation value vector. Therefore, to select a suitable mode for the construction project, it is necessary to consider the actual situation and the project characteristics comprehensively and objectively.

Author Contributions: Conceptualization, L.M. and P.A.; software, L.M. and M.C.; validation, A.A., K.J. and M.C.; formal analysis, P.A. and A.A.; investigation, Y.P.; data curation, P.A. and K.J.; writing-original draft preparation, L.M. and A.A.; writing-review and editing, P.A.; funding acquisition, Y.P. All authors have read and agreed to the published version of the manuscript.

Funding: The present work was financially supported by the National Natural Science Foundation Program of China (no. 31972611), the Hubei Provincial Natural Science Foundation of China (no. 2018CFB512), the Fundamental Research Funds for Central Universities (no. 2662020GXPY006), and the Key Laboratory on Development and Application of Rural Renewable Energy, Ministry of Agriculture. The authors gratefully acknowledge their support.

Conflicts of Interest: The authors declare no conflict of interest.

\section{Nomenclature}

\begin{tabular}{|c|c|}
\hline CR & Crop residue \\
\hline NBSC & National Bureau of Statistics of China \\
\hline ANN & Artificial neural network \\
\hline AHP & Analytical hierarchy process \\
\hline PCP & Principal component projection \\
\hline GRA & Grey relational analysis \\
\hline Mt & Million tons \\
\hline Mtce & Million tons of coal equivalent \\
\hline $\mathrm{AD}$ & Anaerobic digestion \\
\hline AcoD & Anaerobic co-digestion \\
\hline $\mathrm{C} / \mathrm{N}$ & Carbon to nitrogen ratio \\
\hline $\mathrm{CHP}$ & Combined heat and power \\
\hline ICE & Internal combustion engine \\
\hline CNY & Chinese yuan \\
\hline $\mathrm{CO}$ & Carbon monoxide \\
\hline$y_{i}$ & The $i$ th normalized value \\
\hline$x_{i}$ & Original value \\
\hline$x_{\min }$ & The minimum value of $x$ \\
\hline$x_{\max }$ & The maximum value of $x$ \\
\hline$a_{i j}$ & Scale value \\
\hline$W$ & Weight index vector \\
\hline$W_{1}$ & Final weight index \\
\hline$\lambda \max$ & Minimum eigenvalue \\
\hline$i t h$ & Evaluation index \\
\hline$C I$ & Consistency index \\
\hline$C R$ & Consistency ratio \\
\hline$R I$ & Random index \\
\hline$B_{i}$ & Overall evaluation value \\
\hline$z_{i j}$ & Normalized matrix \\
\hline
\end{tabular}




$\begin{array}{ll}\sigma & \text { Corresponding characteristic vector } \\ Z & \text { Characteristic value } \\ P_{i} & \text { Projection value } \\ d^{*} & \text { Row vector }(1) \\ d_{0}^{*} & \text { Unit vector in the direction of } d^{*} \\ d_{i} & \text { Row vector }(2) \\ \varepsilon_{(0 \mathrm{i})}(k) & \text { Relevancy coefficient } \\ \mathrm{Y}_{0}(k) & \text { Series of experimental results } \\ \mathrm{Y}_{i}(k) & \text { Series of influenced factors } \\ \boldsymbol{P} & \text { Distinguishing coefficient } \\ R_{i} & \text { Relational grade }\end{array}$

\section{References}

1. Tripathi, N.; Hills, C.D.; Singh, R.S.; Atkinson, C.J. Biomass waste utilisation in low-carbon products: Harnessing a major potential resource. npj Clim. Atmos. Sci. 2019, 2, 1-10. [CrossRef]

2. Wang, X.; Yang, L.; Steinberger, Y.; Liu, Z.; Liao, S.; Xie, G. Field crop residue estimate and availability for biofuel production in China. Renew. Sustain. Energy Rev. 2013, 27, 864-875. [CrossRef]

3. Qiu, H.; Sun, L.; Xu, X.; Cai, Y.; Bai, J. Potentials of crop residues for commercial energy production in China: A geographic and economic analysis. Biomass Bioenergy 2014, 64, 110-123. [CrossRef]

4. Fang, Y.R.; Wu, Y.; Xie, G.H. Crop residue utilizations and potential for bioethanol production in China. Renew. Sustain. Energy Rev. 2019, 113, 109288. [CrossRef]

5. Ji, L.-Q. An assessment of agricultural residue resources for liquid biofuel production in China. Renew. Sustain. Energy Rev. 2015, 44, 561-575. [CrossRef]

6. Zhang, L.X.; Wang, C.B.; Bahaj, A.S. Carbon emissions by rural energy in China. Renew. Energy 2014, 66, 641-649. [CrossRef]

7. Jiang, D.; Zhuang, D.; Fu, J.; Huang, Y.; Wen, K. Bioenergy potential from crop residues in China: Availability and distribution. Renew. Sustain. Energy Rev. 2012, 16, 1377-1382. [CrossRef]

8. Mathur, R.; Srivastava, V.K. Crop Residue Burning: Effects on Environment; Springer: Singapore, 2019; ISBN 9789811332722.

9. Ren, J.; Yu, P.; Xu, X. Straw utilization in China-status and recommendations. Sustainability 2019, 11, 1762. [CrossRef]

10. Liu, W.; Wang, C.; Mol, A.P.J. Rural residential $\mathrm{CO}_{2}$ emissions in China: Where is the major mitigation potential? Energy Policy 2012, 51, 223-232. [CrossRef]

11. Zeng, X.; Ma, Y.; Ma, L. Utilization of straw in biomass energy in China. Renew. Sustain. Energy Rev. 2007, 11, 976-987. [CrossRef]

12. Boateng, A.A.; Banowetz, G.M.; Steiner, J.J.; Barton, T.F.; Taylor, D.G.; Hicks, K.B.; El-Nashaar, H.; Sethi, V.K. Gasification of Kentucky bluegrass (Poa pratensis 1.) straw in a farm-scale reactor. Biomass Bioenergy 2007, 31, 153-161. [CrossRef]

13. Yang, J.; Wang, X.; Ma, H.; Bai, J.; Jiang, Y.; Yu, H. Potential usage, vertical value chain and challenge of biomass resource: Evidence from China's crop residues. Appl. Energy 2014, 114, 717-723. [CrossRef]

14. Gosens, J.; Lu, Y.; He, G.; Bluemling, B.; Beckers, T.A.M. Sustainability effects of household-scale biogas in rural China. Energy Policy 2013, 54, 273-287. [CrossRef]

15. He, K.; Zhang, J.; Zeng, Y.; Zhang, L. Households' willingness to accept compensation for agricultural waste recycling: Taking biogas production from livestock manure waste in Hubei, China as an example. J. Clean. Prod. 2016, 131, 410-420. [CrossRef]

16. Chen, L.; Xing, L.; Han, L. Renewable energy from agro-residues in China: Solid biofuels and biomass briquetting technology. Renew. Sustain. Energy Rev. 2009, 13, 2689-2695. [CrossRef]

17. Yakaboylu, O.; Harinck, J.; Smit, K.G.; de Jong, W. Supercritical water gasification of biomass: A literature and technology overview. Energies 2015, 8, 859-894. [CrossRef]

18. He, M.; Liu, P.; Ma, L.; Chong, C.; Li, X.; Song, S.; Li, Z.; Ni, W. A systems analysis of the development status and trends of rural household energy in China. Energies 2018, 11, 1741. [CrossRef] 
19. Shen, L.; Liu, L.; Yao, Z.; Liu, G.; Lucas, M. Development potentials and policy options of biomass in China. Environ. Manag. 2010, 46, 539-554. [CrossRef]

20. Hu, J.J.; Zhang, Q.G.; Lei, T.Z.; Wang, Z.W. Experimental study on the wet molding for wheat straw pellet fuel. Adv. Mater. Res. 2011, 156-157, 284-292. [CrossRef]

21. Cherni, J.A.; Dyner, I.; Henao, F.; Jaramillo, P.; Smith, R.; Font, R.O. Energy supply for sustainable rural livelihoods. A multi-criteria decision-support system. Energy Policy 2007, 35, 1493-1504. [CrossRef]

22. Daniel, J.; Vishal, N.V.R.; Albert, B.; Selvarsan, I. Evaluation of the significant renewable energy resources in India using Analytical Hierarchy Process. In Multiple Criteria Decision Making for Sustainable Energy and Transportation Systems; Springer: Berlin/Heidelberg, Germany, 2010; pp. 13-26. Available online: https://link.springer.com/chapter/10.1007/978-3-642-04045-0_2 (accessed on 16 May 2019).

23. Cortazar, M.; Alvarez, J.; Lopez, G.; Amutio, M.; Santamaria, L.; Bilbao, J.; Olazar, M. Role of temperature on gasification performance and tar composition in a fountain enhanced conical spouted bed reactor. Energy Convers. Manag. 2018, 171, 1589-1597. [CrossRef]

24. Wang, S.; Shen, Y. CFD-DEM study of biomass gasification in a fluidized bed reactor: Effects of key operating parameters. Renew. Energy 2020. [CrossRef]

25. Inayat, M.; Sulaiman, S.A.; Bhayo, B.A.; Shahbaz, M. Application of response surface methodology in catalytic co-gasification of palm wastes for bioenergy conversion using mineral catalysts. Biomass Bioenergy 2020, 132, 105418. [CrossRef]

26. Lan, W.; Chen, G.; Ma, W.; Yan, B.; Li, W. Biomass gasification in China. Asia Pac. Power Energy Eng. Conf. APPEEC 2011. [CrossRef]

27. Molino, A.; Chianese, S.; Musmarra, D. Biomass gasification technology: The state of the art overview. J. Energy Chem. 2016, 25, 10-25. [CrossRef]

28. Molino, A.; Larocca, V.; Chianese, S.; Musmarra, D. Biofuels production by biomass gasification: A review. Energies 2018, 11, 811. [CrossRef]

29. Yang, S.; Wang, H.; Wei, Y.; Hu, J.; Chew, J.W. Eulerian-Lagrangian simulation of air-steam biomass gasification in a three-dimensional bubbling fluidized gasifier. Energy 2019, 181, 1075-1093. [CrossRef]

30. Breault, R.W. Gasification processes old and new: A basic review of the major technologies. Energies 2010, 3, 216-240. [CrossRef]

31. Han, J.; Kim, H. The reduction and control technology of tar during biomass gasification/pyrolysis: An overview. Renew. Sustain. Energy Rev. 2008, 12, 397-416. [CrossRef]

32. Susastriawan, A.A.P.; Saptoadi, H. Purnomo Small-scale downdraft gasifiers for biomass gasification: A review. Renew. Sustain. Energy Rev. 2017, 76, 989-1003. [CrossRef]

33. Situmorang, Y.A.; Zhao, Z.; Yoshida, A.; Abudula, A.; Guan, G. Small-scale biomass gasification systems for power generation (<200 kW class): A review. Renew. Sustain. Energy Rev. 2020, 117, 109486. [CrossRef]

34. Bates, R.P.; Dölle, K. Syngas use in internal combustion engines-A review. Adv. Res. 2017, 10, 1-8. [CrossRef]

35. Wang, C.; Zhang, L.; Yang, S.; Pang, M. A hybrid life-cycle assessment of nonrenewable energy and greenhouse-gas emissions of a village-level biomass gasification project in China. Energies 2012, 5, 2708-2723. [CrossRef]

36. Mazaheri, N.; Akbarzadeh, A.H.; Madadian, E.; Lefsrud, M. Systematic review of research guidelines for numerical simulation of biomass gasification for bioenergy production. Energy Convers. Manag. 2019, 183, 671-688. [CrossRef]

37. Möbius, A.; Boukis, N.; Galla, U.; Dinjus, E. Gasification of pyroligneous acid in supercritical water. Fuel 2012, 94, 395-400. [CrossRef]

38. Melapi, A.; Mamphweli, S.N.; Katwire, D.M.; Meyer, E.L. The physical and chemical properties of fine carbon particles-pinewood resin blends and their possible utilization. J. Chem. 2015, 2015. [CrossRef]

39. Prasad, S.; Singh, A.; Korres, N.E.; Rathore, D.; Sevda, S.; Pant, D. Sustainable utilization of crop residues for energy generation: A life cycle assessment (LCA) perspective. Bioresour. Technol. 2020, 303, 122964. [CrossRef]

40. Jat, H.S.; Jat, R.D.; Nanwal, R.K.; Lohan, S.K.; Yadav, A.K.; Poonia, T.; Sharma, P.C.; Jat, M.L. Energy use efficiency of crop residue management for sustainable energy and agriculture conservation in NW India. Renew. Energy 2020, 155, 1372-1382. [CrossRef]

41. Mothe, S.; Polisetty, V.R. Review on anaerobic digestion of rice straw for biogas production. Environ. Sci. Pollut. Res. 2020. [CrossRef] 
42. Ai, P.; Jin, K.; Alengebawy, A.; Elsayed, M.; Meng, L.; Chen, M.; Ran, Y. Effect of application of different biogas fertilizer on eggplant production: Analysis of fertilizer value and risk assessment. Environ. Technol. Innov. 2020, 19, 101019. [CrossRef]

43. Wang, Y.; Wu, X.; Tong, X.; Li, T.; Wu, F. Life cycle assessment of large-scale and household biogas plants in northwest China. J. Clean. Prod. 2018, 192, 221-235. [CrossRef]

44. Samer, M.; Abdelaziz, S.; Refai, M.; Abdelsalam, E. Techno-economic assessment of dry fermentation in household biogas units through co-digestion of manure and agricultural crop residues in Egypt. Renew. Energy 2020, 149, 226-234. [CrossRef]

45. Noonari, A.A.; Mahar, R.B.; Sahito, A.R.; Brohi, K.M. Anaerobic co-digestion of canola straw and banana plant wastes with buffalo dung: Effect of $\mathrm{Fe}_{3} \mathrm{O}_{4}$ nanoparticles on methane yield. Renew. Energy 2019, 133, 1046-1054. [CrossRef]

46. Almomani, F.; Bhosale, R. Enhancing the production of biogas through anaerobic co-digestion of agricultural waste and chemical pre-treatments. Chemosphere 2020, 126805. [CrossRef]

47. Shah, F.A.; Mahmood, Q.; Rashid, N.; Pervez, A.; Raja, I.A.; Shah, M.M. Co-digestion, pretreatment and digester design for enhanced methanogenesis. Renew. Sustain. Energy Rev. 2015, 42, 627-642. [CrossRef]

48. Hagos, K.; Zong, J.; Li, D.; Liu, C.; Lu, X. Anaerobic co-digestion process for biogas production: Progress, challenges and perspectives. Renew. Sustain. Energy Rev. 2017, 76, 1485-1496. [CrossRef]

49. Dima, A.D.; Pârvulescu, O.C.; Mateescu, C.; Dobre, T. Optimization of substrate composition in anaerobic co-digestion of agricultural waste using central composite design. Biomass Bioenergy 2020, 138, 105602. [CrossRef]

50. Huiru, Z.; Yunjun, Y.; Liberti, F.; Bartocci, P.; Fantozzi, F. Technical and economic feasibility analysis of an anaerobic digestion plant fed with canteen food waste. Energy Convers. Manag. 2019, 180, 938-948. [CrossRef]

51. Wang, Q.L.; Li, W.; Gao, X.; Li, S.J. Life cycle assessment on biogas production from straw and its sensitivity analysis. Bioresour. Technol. 2016, 201, 208-214. [CrossRef]

52. Ramírez-Arpide, F.R.; Demirer, G.N.; Gallegos-Vázquez, C.; Hernández-Eugenio, G.; Santoyo-Cortés, V.H.; Espinosa-Solares, T. Life cycle assessment of biogas production through anaerobic co-digestion of nopal cladodes and dairy cow manure. J. Clean. Prod. 2018, 172, 2313-2322. [CrossRef]

53. Pivato, A.; Vanin, S.; Raga, R.; Lavagnolo, M.C.; Barausse, A.; Rieple, A.; Laurent, A.; Cossu, R. Use of digestate from a decentralized on-farm biogas plant as fertilizer in soils: An ecotoxicological study for future indicators in risk and life cycle assessment. Waste Manag. 2016, 49, 378-389. [CrossRef]

54. Topić, D.; Barukčić, M.; Mandžukić, D.; Mezei, C. Optimization model for biogas power plant feedstock mixture considering feedstock and transportation costs using a differential evolution algorithm. Energies 2020, 13, 1610. [CrossRef]

55. Arthurson, V. Closing the global energy and nutrient cycles through application of biogas residue to agricultural land - potential benefits and drawbacks. Energies 2009, 2, 226-242. [CrossRef]

56. Chen, Y.; Yang, G.; Sweeney, S.; Feng, Y. Household biogas use in rural China: A study of opportunities and constraints. Renew. Sustain. Energy Rev. 2010, 14, 545-549. [CrossRef]

57. Meyer-Kohlstock, D.; Haupt, T.; Heldt, E.; Heldt, N.; Kraft, E. Biochar as additive in biogas-production from bio-waste. Energies 2016, 9, 247. [CrossRef]

58. Parra-Ramírez, D.; Solarte-Toro, J.C.; Cardona-Alzate, C.A. Techno-economic and environmental analysis of biogas production from plantain Pseudostem waste in Colombia. Waste Biomass Valorization 2020, 11, 3161-3171. [CrossRef]

59. Solarte-Toro, J.C.; Chacón-Pérez, Y.; Cardona-Alzate, C.A. Evaluation of biogas and syngas as energy vectors for heat and power generation using lignocellulosic biomass as raw material. Electron. J. Biotechnol. 2018, 33, 52-62. [CrossRef]

60. Chen, S.Q.; Li, N.P.; Guan, J.; Ni, J.; Zhou, H.; Sun, F.M.; Xie, Y.Q. Contrastive study between the biomass energy utilization structure and the ecotype energy utilization structure in rural residences-A case in Hunan province, China. Renew. Energy 2009, 34, 1782-1788. [CrossRef]

61. Sheikh, M.M.I.; Kim, C.H.; Park, H.J.; Kim, S.H.; Kim, G.C.; Lee, J.Y.; Sim, S.W.; Kim, J.W. Effect of torrefaction for the pretreatment of rice straw for ethanol production. J. Sci. Food Agric. 2013, 93, 3198-3204. [CrossRef] [PubMed]

62. Behera, S.; Arora, R.; Nandhagopal, N.; Kumar, S. Importance of chemical pretreatment for bioconversion of lignocellulosic biomass. Renew. Sustain. Energy Rev. 2014, 36, 91-106. [CrossRef] 
63. Nguyen, V.H.; Topno, S.; Balingbing, C.; Nguyen, V.C.N.; Röder, M.; Quilty, J.; Jamieson, C.; Thornley, P.; Gummert, M. Generating a positive energy balance from using rice straw for anaerobic digestion. Energy Rep. 2016, 2, 117-122. [CrossRef]

64. Zhang, G.; Sun, Y.; Xu, Y. Review of briquette binders and briquetting mechanism. Renew. Sustain. Energy Rev. 2018, 82, 477-487. [CrossRef]

65. Wang, Y.S.; Yu, P.; Wang, Y.; Zhang, J.; Hang, W.; Yin, Z.X.; Liu, G.; Chen, J.; Werle, K.D.; Quan, C.S.; et al. AMP-activated protein kinase protects against necroptosis via regulation of Keap1-PGAM5 complex. Int. J. Cardiol. 2018, 259, 153-162. [CrossRef] [PubMed]

66. Garrido, M.A.; Conesa, J.A.; Garcia, M.D. Characterization and production of fuel briquettes made from biomass and plastic wastes. Energies 2017, 10, 850. [CrossRef]

67. Niño, A.; Arzola, N.; Araque, O. Experimental study on the mechanical properties of biomass briquettes from a mixture of rice husk and pine sawdust. Energies 2020, 13, 1060. [CrossRef]

68. Chen, G.B.; Li, J.W.; Lin, H.T.; Wu, F.H.; Chao, Y.C. A study of the production and combustion characteristics of pyrolytic oil from sewage sludge using the taguchi method. Energies 2018, 11, 2260. [CrossRef]

69. de Oliveira, R.S.; Palácio, S.M.; Da Silva, E.A.; Mariani, F.Q.; Reinehr, T.O. Briquettes production for use as power source for combustion using charcoal thin waste and sanitary sewage sludge. Environ. Sci. Pollut. Res. 2017, 24, 10778-10785. [CrossRef]

70. Schipfer, F.; Kranzl, L. Techno-economic evaluation of biomass-to-end-use chains based on densified bioenergy carriers (dBECs). Appl. Energy 2019, 239, 715-724. [CrossRef]

71. Blair, M.J.; Mabee, W.E. Evaluation of technology, economics and emissions impacts of community-scale bioenergy systems for a forest-based community in Ontario. Renew. Energy 2020, 151, 715-730. [CrossRef]

72. Kruszelnicka, W. New model for ecological assessment of comminution process in energy biomass processing chain. E3S Web Conf. 2020, 154, 1-21. [CrossRef]

73. Vasconcelos, M.H.; Mendes, F.M.; Ramos, L.; Dias, M.O.S.; Bonomi, A.; Jesus, C.D.F.; Watanabe, M.D.B.; Junqueira, T.L.; Milagres, A.M.F.; Ferraz, A.; et al. Techno-economic assessment of bioenergy and biofuel production in integrated sugarcane biorefinery: Identification of technological bottlenecks and economic feasibility of dilute acid pretreatment. Energy 2020, 199. [CrossRef]

74. Kang, Y.; Yang, Q.; Bartocci, P.; Wei, H.; Liu, S.S.; Wu, Z.; Zhou, H.; Yang, H.; Fantozzi, F.; Chen, H. Bioenergy in China: Evaluation of domestic biomass resources and the associated greenhouse gas mitigation potentials. Renew. Sustain. Energy Rev. 2020, 127, 109842. [CrossRef]

75. Zang, C.; Imregun, M. Structural damage detection using artificial neural networks and measured FRF data reduced via principal component projection. J. Sound Vib. 2001, 242, 813-827. [CrossRef]

76. Naesens, K.; Gelders, L.; Pintelon, L. A swift response framework for measuring the strategic fit for a horizontal collaborative initiative. Int. J. Prod. Econ. 2009, 121, 550-561. [CrossRef]

77. Moran, J.C.; Miguez, J.L.; Porteiro, J.; Patiño, D.; Granada, E.; Collazo, J. Study of the feasibility of mixing Refuse Derived Fuels with wood pellets through the grey and Fuzzy theory. Renew. Energy 2009, 34, 2607-2612. [CrossRef]

78. BaiMing, C.; ZhengFeng, Z.; AnNing, C. Case analysis of crop straw gasification use technology and commercialization operation. Trans. Chin. Soc. Agric. Eng. 2005, 21, 124-128.

79. Zhang, H.; Liu, Y.; Wang, G. Integrated Use of Maize Bran Residue for One-Step Phosphate Bio-Fertilizer Production. Appl. Biochem. Biotechnol. 2019, 187, 1475-1487. [CrossRef] [PubMed]

80. Smitha, G.R.; Basak, B.B.; Thondaiman, V.; Saha, A. Nutrient management through organics, bio-fertilizers and crop residues improves growth, yield and quality of sacred basil (Ocimum sanctum Linn). Ind. Crops Prod. 2019, 128, 599-606. [CrossRef]

81. Huang, R.; Hubacek, K.; Feng, K.; Li, X.; Zhang, C. Re-examining embodied $\mathrm{SO}_{2}$ and $\mathrm{CO}_{2}$ emissions in China. Sustainability 2018, 10, 1505. [CrossRef]

82. Kusumaningtyas, R.D.; Prasetiawan, H.; Astuti, W.; Pita Rengga, W.D.; Aji Muhammad, D.R. Design and Construction of Microwave-Assisted Pyrolysis of Waste Coconut Shell for the Isolation of Pyroligneous Acid. KnE Soc. Sci. 2019, 2019, 544-553. [CrossRef]

83. Li, W.; Liu, Z. A method of SVM with normalization in intrusion detection. Procedia Environ. Sci. 2011, 11, 256-262. [CrossRef]

84. Chen, J.F.; Hsieh, H.N.; Do, Q.H. Evaluating teaching performance based on fuzzy AHP and comprehensive evaluation approach. Appl. Soft Comput. J. 2015, 28, 100-108. [CrossRef] 
85. Wu, C.; Shang, J. Research on model of agricultural machinery selection based on principal component projection. In Proceedings of the 2011 International Conference on Electronic \& Mechanical Engineering and Information Technology, Harbin, China, 12-14 August 2011; Volume 7, pp. 3591-3594. Available online: https://ieeexplore.ieee.org/abstract/document/6023841 (accessed on 16 May 2019). [CrossRef]

86. Putra, M.S.D.; Andryana, S.; Kasyfi, F.; Gunaryati, A. Fuzzy analytical hierarchy process method to determine the quality of gemstones. Adv. Fuzzy Syst. 2018, 2018. [CrossRef]

87. Yucheng, W.; Baoguo, M.; Zhaohan, S. Ranking method for the reciprocal judgment matrix based on the unascertained three-valued judgments. J. Syst. Eng. Electron. 2006, 17, 115-120. [CrossRef]

88. Wang, H.; Lahdelma, R.; Salminen, P. Complementary Judgment Matrix Method with Imprecise Information for Multicriteria Decision-Making. Math. Probl. Eng. 2018, 2018, 1-11. [CrossRef]

89. Wang, M.-K.; Hwang, K.P. Using FAHP methods evaluation and screening of intellectual property rights managers in Taiwan. Asia Pac. J. Oper. Res. 2014, 31, 1450048. [CrossRef]

90. Hazelrigg, G.A. A Note on the Weighted Sum Method. J. Mech. Des. 2019, 141, 100301. [CrossRef]

91. Bhuyan, R.; Routara, B. Optimization the machining parameters by using VIKOR and Entropy Weight method during EDM process of Al-18\% SiCp Metal matrix composite. Decis. Sci. Lett. 2016, 5, $269-282$. [CrossRef]

92. Rothe, S.; Ebert, S.; Schütze, H. Ultradense word embeddings by orthogonal transformation. arXiv 2016, arXiv:1602.07572.

93. Yuan, Z.; Zhu, X.; Yang, J.; Wang, W. Research on Case Library Construction of Energy Loss In Country Distribution Networks with Grey Relational Analysis. In Proceedings of the 2015 th National Conference on Electrical, Electronics and Computer Engineering, Xi'an, China, 12-13 December 2015; pp. 1480-1483. [CrossRef]

94. Fang, F.; Jiang, H.; Wang, J.; Yu, H.-Q. Identifying the influential priority of the factors governing PHB production by activated sludge with integration of uniform design and grey relational analysis. Sep. Purif. Technol. 2014, 136, 111-114. [CrossRef]

95. Wang, Z.; Li, J.; Liu, J.; Shuai, C. Is the photovoltaic poverty alleviation project the best way for the poor to escape poverty?-A DEA and GRA analysis of different projects in rural China. Energy Policy 2020, 137, 111105. [CrossRef]

96. Xu, M.; Zhu, Q.; Wu, J.; He, Y.; Yang, G.; Zhang, X.; Li, L.; Yu, X.; Peng, H.; Wang, L. Grey relational analysis for evaluating the effects of different rates of wine lees-derived biochar application on a plant-Soil system with multi-metal contamination. Environ. Sci. Pollut. Res. 2018, 25, 6990-7001. [CrossRef] [PubMed]

97. Aslan, N.; Shahrivar, A.A.; Abdollahi, H. Multi-objective optimization of some process parameters of a lab-scale thickener using grey relational analysis. Sep. Purif. Technol. 2012, 90, 189-195. [CrossRef] 